\title{
A Study on the Relationship between Microbial Growth, Histamine Development and Organoleptic Changes in Retailed Fresh Sprangled Emperor and Big Eye Tuna
}

\author{
Samiirah Chummun and Hudaa Neetoo* \\ Department of Agriculture and Food Science, Faculty of Agriculture, University of Mauritius, Mauritius
}

Correspondence to:

Hudaa Neetoo

Department of Agriculture and Food Science

Faculty of Agriculture

University of Mauritius Mauritius

E-mail: s.neetoo@uom.ac.mu

Received: October 21, 2015

Accepted: January 25, 2016

Published: January 27, 2016

Citation: Chummun S, Neetoo H. 2016. A Study on the Relationship between Microbial Growth, Histamine Development and Organoleptic Changes in Retailed Fresh Sprangled Emperor and Big Eye Tuna. J Food Chem Nanotechnol 2(1): 6-13.

Copyright: (C) 2016 Chummun and Neetoo. This is an Open Access article distributed under the terms of the Creative Commons Attribution 4.0 International License (CC-BY) (http:// creativecommons.org/licenses/by/4.0/) which permits commercial use, including reproduction, adaptation, and distribution of the article provided the original author and source are credited.

Published by United Scientific Group

\begin{abstract}
The safety of fresh fish is often compromised due to contamination by bacterial human pathogens and histamine-forming bacteria. In addition, the quality of fish is also adversely affected during proliferation of spoilage microorganisms thus reducing their shelf life. The purpose of the study was to comparatively assess the safety and quality of non-scombroid fish 'Sprangled Emperor' (Lethrinus nebulosus) and scombroid fish 'Big Eye Tuna' (Thunnus obesus) purchased from market and supermarket using sensorial, microbiological, histamine and molecular analyses. Fish sold in market and supermarket were sampled at two time points: T0 (immediately upon display) and T8 (eight hours after display). Microbial load of fish samples was determined by enumeration of Total Viable Counts (TVC), Vibrio spp., Clostridium perfringens, Pseudomonas spp., marine organisms and spoilage yeasts and molds. Fish were also subjected to histamine testing by the AOAC method. Sensorial evaluation of fish samples for organoleptic traits such as overall appearance, color, odor and texture was also carried out at both time points. An increase in the microbial load of 'Sprangled Emperor' (SE) and 'Big Eye Tuna' (BET) purchased from both market and supermarket was generally observed after eight hours of display; TVC increase was higher in SE $(\Delta=0.7 \mathrm{log} \mathrm{cfu} / \mathrm{g})$ compared to BET $(\Delta=0.3 \mathrm{log} \mathrm{cfu} / \mathrm{g})$ although the difference was not significant $(\mathrm{P}>0.05)$. The level of marine organisms, C. perfringens and Pseudomonas spp. were significantly higher $(\mathrm{P}<0.05)$ after eight hours of display. Initial sensory scores of fish purchased from market were significantly higher than those of supermarket $(\mathrm{P}<0.05)$ and marked sensorial quality deterioration was noted after eight hours of display. Histamine testing revealed a lower level of histamine for SE (<2.3 ppm) compared to BET (1-8 ppm) at both time-points. Findings of this study showed that displaying fish for $\geq$ eight hours at retail can considerably compromise the safety and quality of scombroid fish such as tuna.
\end{abstract}

\section{Keywords}

Fish, Tuna, Emperor, Pathogens, Spoilage, Histamine

\section{Introduction}

Fish is one of the most significant sources of protein for human consumption worldwide. Fresh fish is presumed to have a higher nutritive value compared to other types of fish. However, the quality of fresh fish is known to deteriorate quickly. According to Gram and Huss [1], fresh fish is a product that is extremely perishable and has a short shelf-life as a result of microbial growth and activity, which result in changes in the sensorial characteristics. Fresh unpreserved fish is spoilt by gram-positive fermentative bacteria belonging to the genus Bacillus, Clostridium and Lactobacillus, while chilled fish are mainly spoilt by psychrotolerant gram-negative bacteria belonging to the genus Vibrionaceae, 
Pseudomonas and Shewanella [2]. Furthermore, certain bacterial species belonging to the family of Enterobacteriaceae, Bacillaceae, Vibrionaceae and Clostridiaceae family produce elevated levels of histamine, which can lead to scombroid poisoning, dizziness, diarrhea and respiratory diseases among others $[3,4]$. For fresh fish to be consumed safely, the level of histamine should not exceed $50 \mathrm{ppm}$ [3]. The aim of the project was to characterize the spoilage and histamine forming bacteria in fresh 'Sprangled Emperor'(Lethrinus nebulosus) and 'Big Eye Tuna' (Thunnus obesus) during display in a market or in a supermarket at ambient or chilled temperature respectively as well as study the relationship between microbial spoilage, histamine development and organoleptic deterioration.

\section{Materials and Methods}

\section{Sample collection}

Samples of SE and BET fish were purchased from a market and a supermarket located in the Capital City of Mauritius, Port-Louis. Fish were purchased immediately upon display (T0) and after eight hours of display (T8). Fish sold in market and supermarket, were displayed at ambient and chilling temperatures respectively. Once purchased, fish samples were aseptically placed in sterile plastic bags, which were kept in a cooler bag containing ice packs to minimize temperature abuse during transportation. Samples were transported to the laboratory for analysis within one hour of sample collection and subjected to sensorial, microbiological and histamine analyses as described below.

\section{Organoleptic evaluation}

Questionnaire was designed and adapted from the quality index method (QIM) [5,6] for sensory evaluation of $\mathrm{SE}$ and BET fish. A ranking scale with scores of 0 to 3 was used for assessment whereby '0' meant 'highly desirable' and 3 meant 'unacceptable'. The parameters for sensory evaluation included general appearance, smell, color and texture of fish. The questionnaires were filled by a group of 25 people who evaluated one and three samples of BET and SE fish respectively and the mean scores calculated. Three independent trials were conducted.

\section{Histamine analysis}

Histamine in the fish was analyzed using the fluorometric method [7]. Briefly, $10 \mathrm{~g}$ of homogenized sample of the fish was weighed and $75 \%$ of methanol (Sigma-Aldrich, Sydney, Australia) was added. The mixture was then homogenized and the homogenate was transferred into a $100 \mathrm{ml}$ volumetric flask and made up to the $100 \mathrm{ml}$ mark with $75 \%$ methanol. The flask was shaken and left to stand for 15 minutes. $1 \mathrm{ml}$ of the supernatant was then pipetted through an $8 \mathrm{~cm}$ packed ion exchange resin. About 5-10 $\mathrm{ml}$ distilled water was added to wash the column and the tap was opened to collect the eluate in a $50 \mathrm{ml}$ volumetric flask containing $5 \mathrm{ml} 1 \mathrm{M} \mathrm{HCL}$ (Sigma-Aldrich, Sydney, Australia). The flask was then made up to the mark using distilled water. $5 \mathrm{ml}$ of the eluted sample was transferred to a $50 \mathrm{ml}$ corning tube. For the control, 5 $\mathrm{ml}$ of $0.1 \mathrm{ml} \mathrm{HCL}$ was used. $10 \mathrm{ml}$ of $0.1 \mathrm{M} \mathrm{HCL}$ was then added in each corning tube and vortexed. $3 \mathrm{ml}$ of $1 \mathrm{M} \mathrm{NAOH}$ was further dispensed and vortexed. After $4 \mathrm{~min}, 1 \mathrm{ml}$ of
0.1\% OPT (Sigma-Aldrich, St Louis, USA) was added and vortexed. After 4 minutes, $3 \mathrm{ml}$ of $4 \mathrm{M} \mathrm{H}_{3} \mathrm{PO}_{4}$ (Sigma-Aldrich, Sydney, Australia) was added and vortexed. The sample was then allowed to stand for 15 minutes. The reading was taken using a fluorimeter.

\section{$\mathrm{pH}$ determination}

Fish meat and water were mixed in a 1:5 ratio using a homogenizer. The $\mathrm{pH}$ of the fish homogenate was measured using a $\mathrm{pH}$ meter (Mettler Toledo, Switzerland).

\section{Microbial analysis}

$25 \mathrm{~g}$ of fish was aseptically measured and transferred to a stomacher bag. A volume of $225 \mathrm{ml}$ of buffered peptone water (BPW) (Oxoid, Hampshire, UK) was added. The mixture was homogenized (Stomacher 400, Seward, UK) for 2 minutes at $230 \mathrm{rpm}$ producing a homogeneous stomachate sample. The homogenate was serially diluted and plated as described below.

\section{Microbial load}

Enumeration of Total Viable Count was done by pour plating on Plate Count Agar (HiMedia, Mumbai, India) and plates incubated at $30{ }^{\circ} \mathrm{C}$ for 72 hours (ISO 4833:2003). Enumeration of yeast and mold was done by spread plating on Potato Dextrose Agar (Oxoid, Hampshire, UK) and plates incubated at $30{ }^{\circ} \mathrm{C}$ for 72 hours (ISO 21527:2008). Enumeration of marine organisms was done by pour plating on Marine Agar (HiMedia, Mumbai, India) and incubated at $30{ }^{\circ} \mathrm{C}$ for 72 hours. Enumeration of Clostridium perfringens was carried out on Iron Sulfite Agar (Oxoid, Hampshire, UK) and plates incubated at $37^{\circ} \mathrm{C}$ for 24 hours (ISO 7937:2004).

Isolation and identification of Pseudomonas and Vibrio species

Suspect Pseudomonas species were isolated using the spread plating method on Pseudomonas agar (Oxoid, Hampshire, UK) [8] followed by incubation of plates at $42{ }^{\circ} \mathrm{C}$ for 24 hours. The bacterial isolates were identified by microscopic examination and then subjected to biochemical tests namely Oxidase, Catalase and Methyl Red and VogesProskauer test and molecular analysis for identification. Presumptive Vibrio species were isolated using the spread plating method on chromogenic agar (HiMedia, Mumbai, India) and Thiosulfate-citrate-bile salts-sucrose agar (Oxoid, Hampshire, UK), followed by incubation at $37^{\circ} \mathrm{C}$ for 24 hours (ISO/TS 21872-1:2007).

\section{PCR identification of the bacterial isolates}

The bacterial isolates were identified by PCR according to the method of Cheng and Jiang [9]. Briefly, the isolated microorganisms were inoculated in Luria and Bertani broth at $37^{\circ} \mathrm{C}$ for $24 \pm 2$ hours in a shaker. An aliquot $(2 \mathrm{ml})$ of the cell suspension was then transferred to a corning tube and centrifuged at $8000 \mathrm{rpm}$ for 10 minutes. The pellet was suspended in $560 \mu \mathrm{l}$ Tris EDTA (TE) buffer, $50 \mu 110 \%$ Sodium Dodecyl Sulfate (SDS) and $5 \mu$ Proteinase K, followed by incubation at $55{ }^{\circ} \mathrm{C}$ for 1 hour. An aliquot of $250 \mu \mathrm{l}$ Cetyl Trimethylammonium Bromide (CTAB) and $350 \mu 5 \mathrm{M}$ Sodium Chloride was then added and mixed followed by incubation at $55{ }^{\circ} \mathrm{C}$ for 1 hour. Equal volume of chloroform/isoamyl alcohol (24:1) was added and mixed, 
followed by centrifugation for 15 minutes at $8000 \mathrm{rpm}$. The top layer was then transferred to a new corning tube and equal volume of $95 \%$ alcohol was added, followed by centrifugation at $8000 \mathrm{rpm}$ for 10 minutes. The pellet DNA was washed with $70 \%$ ethanol twice and then placed in the vacuum dryer for 20 minutes at $50{ }^{\circ} \mathrm{C}$. The pellet was finally dissolved in $50 \mu \mathrm{TE}$ buffer and stored at $-20{ }^{\circ} \mathrm{C}$. Genomic DNA was amplified using the Applied Biosystems 2720 thermal cycler (ThermoFisher, CA, USA) with the $25 \mu \mathrm{l}$ PCR mix containing $2.5 \mu \mathrm{l}$ Buffer $/ \mathrm{MgCl}_{2}, 2 \mu \mathrm{d}$ dNTs, $0.5 \mu$ Forward primer, $0.5 \mu \mathrm{l}$ Reverse primer, $0.2 \mu \mathrm{l}$ Taq polymerase, $1 \mu \mathrm{l}$ DNA template and $18.3 \mu 1$ sterile distilled water. To identify Pseudomonas and Vibrio species, the universal primers $16 \mathrm{~S}$ -F (5' AGTTTGATCATGGCTCAG 3') and 16S -R (5 TTACCGCGGCTGGCA 3') were used. Amplification was performed using $30 \mathrm{PCR}$ cycles, each consisting of an initial denaturation step at $95{ }^{\circ} \mathrm{C}$ for 2 minutes, 30 cycles of $95{ }^{\circ} \mathrm{C}$ for 1 minutes, $53{ }^{\circ} \mathrm{C}$ for 30 secs and $72{ }^{\circ} \mathrm{C}$ for 1 minutes, followed by a final extension at $72{ }^{\circ} \mathrm{C}$ for 5 minutes and 30 cycles. The $500 \mathrm{bp}$ amplicon was identified by agarose gel electrophoresis. The PCR products were purified using the QIAGEN purification kit (Qiagen, Manchester, UK) and sent to Inqaba Biotechnical Industries (Pty) Ltd for sequencing. Bioinformatics tools were then used to identify the sequences.

Direct microbial DNA extraction from the fish matrix to identify $M$. morganii and S. putrefaciens

The method used for DNA extraction was adapted from Bardaki and Skibinski [10]. Briefly, an amount of 0.2 $\mathrm{g}$ minced fish sample was transferred into a $15 \mathrm{ml}$ corning tube. An aliquot of $1000 \mu \mathrm{l}$ of Sodium-Chloride-Tris EDTA (STE), $30 \mu \mathrm{l}$ SDS and $60 \mu \mathrm{l}$ proteinase $\mathrm{K}$ were then added. The sample was briefly vortexed and incubated at $55{ }^{\circ} \mathrm{C}$ for 3 hours. DNA was purified using an equal volume of phenol: chloroform: isoamyl alcohol $(25: 24: 1)$, followed by centrifugation at $8000 \mathrm{rpm}$ for 10 minutes. The supernatant was then transferred to a new $15 \mathrm{ml}$ corning tube and equal volume of chloroform: isoamyl alcohol (24:1) was added, followed by centrifugation at $8000 \mathrm{rpm}$ for 10 minutes. The top layer was then transferred to a new $15 \mathrm{ml}$ corning tube and an equal volume of $95 \%$ alcohol was then added, followed by centrifugation at $8000 \mathrm{rpm}$ for 10 minutes. The DNA pellet was washed with $70 \%$ ethanol twice and dried in the vacuum for 20 minutes at $50{ }^{\circ} \mathrm{C}$ The pellet was finally dissolved in $50 \mu \mathrm{lTE}$ buffer and stored at $-20^{\circ} \mathrm{C}$. The genomic DNA was amplify using the Applied Biosystems 2720 thermal cycler with the $25 \mu \mathrm{l}$ PCR mix (same components as above). Primers Mm453F (5'-TTTCAGTCGGGAGGAAGGTG-3') and Mm631R (5'-GGGGATTTCACATCTGACTC-3') were used to amplified the conserved region of $M$. morganii while primers SP-1 (5'TTCGTCGATTATTTGAACAGT 3') and SP-2r (5' TTTTCCAGCAGATAATCGTTC 3`) were used to identify $S$. putrefaciens. Amplification of both amplicons was carried out using Applied Biosystems 2720 thermal cycler programmed as follows: an initial denaturation step at $95{ }^{\circ} \mathrm{C}$ for 2 minutes, 30 cycles of $94{ }^{\circ} \mathrm{C}$ for 1 minutes, $65{ }^{\circ} \mathrm{C}$ for $45 \mathrm{sec}$ and $72{ }^{\circ} \mathrm{C}$ for 2 minutes, followed by a final extension at $72{ }^{\circ} \mathrm{C}$ for 7 minutes. The PCR products were identified by agarose gel electrophoresis and then sequenced.

\section{Statistical analysis}

All analyses were conducted in at least two independent trials. A single-factor ANOVA was used to analyze data obtained and Tukey's one-way multiple comparisons were conducted to determine differences in the population of the different bacterial species for fish purchased in the market vs. supermarket. Significant differences were considered at the 95\% confidence level $(\mathrm{P}<0.05)$.

\section{Results and Discussion}

This section describes and explains findings garnered in this study on the safety, quality and 'freshness' of fish assessed using a combination of sensorial evaluation techniques as well as microbiological, histamine, physicochemical and molecular analyses immediately upon and eight hours after display under ambient and chilled temperature conditions. There was a greater increase in the QIM score of fresh fish sold at the market following the 8-hour display than fish sold at the supermarket. The TVC load of both fish species sold at both retail outlets was also found to increase over the 8-hour display. Big Eye Tuna (BET), which is a scombroid fish, was found to harbor higher levels of histamine than Sprangled Emperor (SE) fish, a non-scombroid fish. The level of histamine was found to increase after eight hours of display, however levels did not exceed $20 \mathrm{ppm}$.

\section{Sensory evaluation}

\section{Big Eye Tuna (BET)}

BET purchased from the market [Figure 1A] at T0 was firmer, more elastic, redder in color, bloodier and more freshlike than that from the supermarket [Figure 1C], which was paler, more dull in color and softer in texture. BET from both the market [Figure 1B] and the supermarket [Figure 1D] underwent a slight change in color and texture at T8. BET purchased from the market had a generally lower mean QIM score at T0 compared to those purchased in supermarket [Table 1]. Additionally, the mean general QIM score for

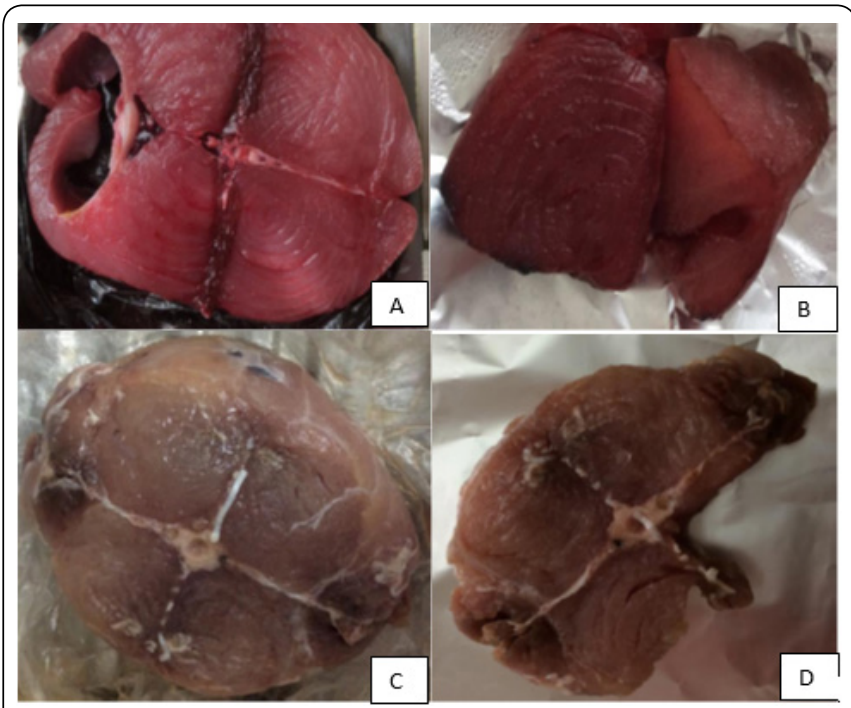

Figure 1: Visual appearance of big eye tuna (Thunnus obesus) purchased from market and supermarket immediately upon display (T0) and after 8 hours of display (T8) (A: Market T0, B: Market T8, C: Supermarket T0 and D: Supermarket T8). 
BET fish purchased from the market at T8 was significantly higher than at T0 $(\mathrm{P}<0.05)$, while there were no significant differences between the $\mathrm{T} 0$ and $\mathrm{T} 8$ scores for fish purchased from supermarket [Table 1]. Quality deterioration of BET purchased from the market was more pronounced than their supermarket counterparts probably due to differences in the display temperature. Table 1 depicts the individual QIM scores for BET purchased from market and supermarket at T0 and T8 for quality parameters such as flesh texture, flesh color, fish odor and flesh opacity.

Table 1: Mean QIM score for the sensorial evaluation of BET.

\begin{tabular}{|l|c|c|c|c|}
\hline \multirow{2}{*}{ Parameters } & \multicolumn{2}{|c|}{ Market } & \multicolumn{2}{c|}{ Supermarket } \\
\cline { 2 - 5 } & T0 & T8 & T0 & T8 \\
\hline Flesh texture & $0.0 \pm 0.00^{\mathrm{a}}$ & $1.9 \pm 0.46^{\mathrm{b}}$ & $2.0 \pm 0.40^{\mathrm{a}}$ & $2.7 \pm 0.12^{\mathrm{a}^{\mathrm{a}}}$ \\
\hline Flesh color & $0.3 \pm 0.12^{\mathrm{a}}$ & $2.0 \pm 0.00^{\mathrm{b}}$ & $2.4 \pm 0.60^{\mathrm{a}}$ & $2.7 \pm 0.12^{\mathrm{a}^{\mathrm{a}}}$ \\
\hline Fish odor & $0.0 \pm 0.00^{\mathrm{a}}$ & $1.0 \pm 0.00^{\mathrm{b}}$ & $1.0 \pm 0.00^{\mathrm{a}}$ & $1.0 \pm 0.00^{\mathrm{a}}$ \\
\hline Flesh opacity & $0.0 \pm 0.00^{\mathrm{a}}$ & $1.5 \pm 0.12^{\mathrm{b}}$ & $1.7 \pm 0.12^{\mathrm{a}}$ & $2.0 \pm 0.40^{\mathrm{a}}$ \\
\hline
\end{tabular}

: Mean values within the same row for the same retail outlet having the same superscript letters (e.g. “a”) are not significantly different $(\mathrm{P}>0.05)$

Sprangled Emperor (SE)

The initial (T0) skin appearance of SE purchased from the market was brighter and shinier than that from supermarket (data not shown). After eight hours (T8), the skin appearance of the fish lost its natural luster and became duller. The eye clarity of SE was more pronounced at $\mathrm{T} 0$ in samples analyzed from the market than those from the supermarket (data not shown). Eye clarity was lower at T8 for SE samples purchased from both retail outlets. The bright blood red color of gills characteristic of fresh fish was noted at T0 from both retail sites and the red color faded after eight hours of display (data not shown). At T0, the flesh evaluated from the market [Figure $2 \mathrm{~A}]$ was firmer, more elastic and glossier as compared to that from the supermarket [Figure 2C]. However, at T8, the texture and color of the flesh from both retail sites had undergone a change, with a more pronounced difference observed in fish purchased from market. As expected, the mean QIM scores
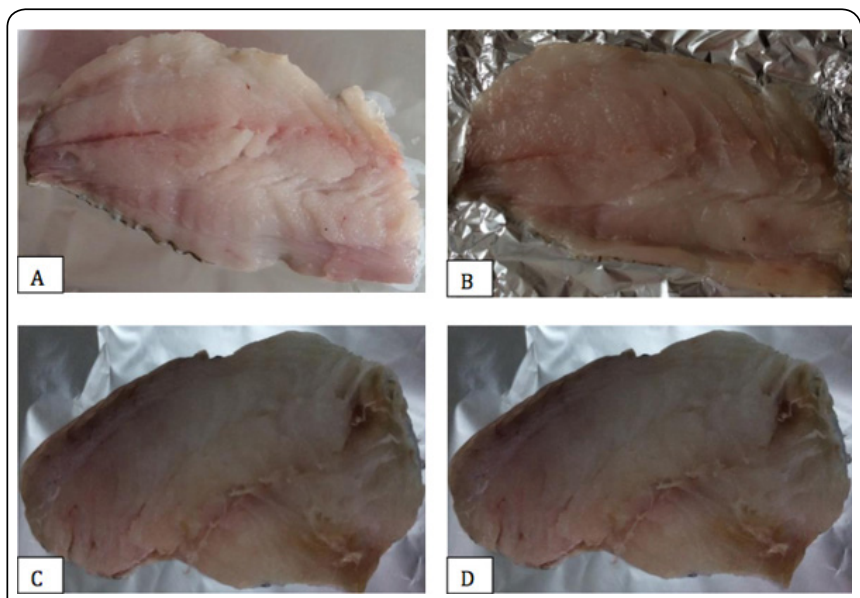

Figure 2: Visual appearance of emperor fish (Letbrinus nebulosus) purchased from market and supermarket immediately upon display (T0) and 8 hours after display (T8) (A: Market T0, B: Market T8, C: Supermarket T0 and D: Supermarket T8). increased after 8 hours of display; the increase in the mean QIM scores from T0 to T8 was higher for SE purchased from the market $(\mathrm{P}<0.05)$ than that from the supermarket $(P>0.05)$. Table 2 indicates the mean QIM scores for quality parameters such as skin appearance, flesh color, fish odor, flesh opacity, blood on gill, eye clarity, eye shape and gill odour for $\mathrm{SE}$ fish purchased from market and supermarket at T0 and T8. As observed in Table 2, QIM scores increased with display time. Lowest QIM points are usually scored in fresh fish soon after its catch [11] and this score is known to increase linearly [12] with storage time until a maximum score is reached at the end of its shelf life. Naive panelists were involved in the sensory evaluation process to simulate typical consumers and therefore they were not trained. Overall, their assessment was quite uniform and resulted in minimal spread in the scores. As stated by Sveinsdottir et al. [12], a QIM scheme should have low variations in the scores when comparing individual panelist scores.

Table 2: Mean QIM score for the sensorial evaluation of SE.

\begin{tabular}{|l|c|c|c|c|}
\hline \multirow{2}{*}{ Parameters } & \multicolumn{2}{|c|}{ Market } & \multicolumn{2}{c|}{ Supermarket } \\
\cline { 2 - 5 } & T0 & T8 & T0 & T8 \\
\hline Skin appearance & $0.4 \pm 0.00^{\mathrm{a}}$ & $1.2 \pm 0.20^{\mathrm{b}}$ & $1.4 \pm 0.20^{\mathrm{a}}$ & $2.1 \pm 0.12^{\mathrm{a}^{\mathrm{a}}}$ \\
\hline Flesh color & $0.0 \pm 0.00^{\mathrm{a}}$ & $1.5 \pm 0.12^{\mathrm{b}}$ & $0.5 \pm 0.12^{\mathrm{a}}$ & $0.6 \pm 0.00^{\mathrm{a}^{\mathrm{a}}}$ \\
\hline Fish odor & $0.0 \pm 0.00^{\mathrm{a}}$ & $1.0 \pm 0.00^{\mathrm{b}}$ & $1.0 \pm 0.00^{\mathrm{a}}$ & $1.0 \pm 0.20^{\mathrm{a}^{\mathrm{a}}}$ \\
\hline Blood on gill & $2.8 \pm 0.20^{\mathrm{a}}$ & $1.9 \pm 0.30^{\mathrm{a}}$ & $1.2 \pm 0.20^{\mathrm{a}}$ & $1.0 \pm 0.20^{\mathrm{a}^{\mathrm{a}}}$ \\
\hline Eye clarity & $0.0 \pm 0.00^{\mathrm{a}}$ & $0.5 \pm 0.12^{\mathrm{a}}$ & $0.0 \pm 0.00^{\mathrm{a}}$ & $0.0 \pm 0.00^{\mathrm{a}^{\mathrm{a}}}$ \\
\hline Eye shape & $0.3 \pm 0.12^{\mathrm{a}}$ & $1.4 \pm 0.20^{\mathrm{b}}$ & $1.0 \pm 0.00^{\mathrm{a}}$ & $1.0 \pm 0.20^{\mathrm{a}^{\mathrm{a}}}$ \\
\hline Gill odor & $0.1 \pm 0.12^{\mathrm{a}}$ & $0.8 \pm 0.10^{\mathrm{a}}$ & $1.0 \pm 0.00^{\mathrm{a}}$ & $1.1 \pm 0.12^{\mathrm{a}^{\mathrm{a}}}$ \\
\hline Flesh texture & $0.1 \pm 0.12^{\mathrm{a}}$ & $1.7 \pm 0.12^{\mathrm{b}}$ & $0.6 \pm 0.35^{\mathrm{a}}$ & $0.9 \pm 0.12^{\mathrm{a}^{\mathrm{a}}}$ \\
\hline
\end{tabular}

: Mean values within the same row for the same retail outlet having the same superscript letters (e.g. “" ${ }^{\text {") }}$ ) are not significantly different $(\mathrm{P}>0.05)$.

\section{Histamine analysis}

A significantly $(\mathrm{P}<0.05)$ higher level of histamine was detected in BET (scombroid fish) analyzed from the supermarket at both time intervals (T0: $7.32 \mathrm{ppm}$; T8: $17.2 \mathrm{ppm}$ ) than that from the market (T0: $1.31 \mathrm{ppm}$; T8: 2.33) [Table 3]. The level of histamine detected in SE (nonscombroid fish) was quite low and there was no significant difference $(p>0.05)$ in the mean histamine level of SE between market and supermarket at both time intervals. According to Auerswald et al. [13], analysis of scombroid and non-scombroid fresh seafood species in South Africa yielded low levels of histamine (0-9 ppm) except for one sample of snoek (scombroid fish) and one sample of yellowtail (scombroid fish) where the level of histamine was greater than $50 \mathrm{ppm}$ for both. Joshi and Bhoir [14], reported that the level of histamine detected in commercial scombroid fish samples namely fresh Indian mackerel (Rastrelliger kanagurta) and fresh sardines (Sardinella gibbosa) in Kalyan city in India were between 20-30 ppm. However, it is stated by many authors that low levels of histamine ( $>1 \mathrm{ppm}$ ) are measured in freshly 
Table 3: Mean histamine level (ppm) detected in both fish species at both retail outlets.

\begin{tabular}{|c|c|c|c|c|}
\hline & \multicolumn{2}{|c|}{ Market } & \multicolumn{2}{c|}{ Supermarket } \\
\hline Fish species & T0 & T8 & T0 & T8 \\
\hline BET & $1.31 \pm 0.73^{\mathrm{a}}$ & $2.33 \pm 1.53^{\mathrm{a}}$ & $7.32 \pm 5.08^{\mathrm{b}}$ & $17.2 \pm 7.41^{\mathrm{b}^{\mathrm{a}}}$ \\
\hline SE & $1.41 \pm 0.20^{\mathrm{a}}$ & $2.28 \pm 2.53^{\mathrm{a}}$ & $2.19 \pm 1.66^{\mathrm{a}}$ & $1.84 \pm 1.85^{\mathrm{a}^{\mathrm{a}}}$ \\
\hline
\end{tabular}

*: Mean values within the same row having the same superscript letters (e.g. “" “") are not significantly different $(\mathrm{P}>0.05)$.

caught scombroid species such as Skipjack (Katsuwonus pelamis) [15] and black Skipjack (Euthynnus lineatus) [16]. It is widely reported that scombroid fishes produce higher histamine level as compared to non-scombroid fishes as the former ones have high level of histidine amino acids in their tissue and when they die, endogenous histidine decarboxylase catalyzes the decarboxylation of histidine to form histamine. The production of histamine in fish is also dependent on the muscle type of the fish (dark or white), individual parts of the fish and the size of the fish $[17,18]$. Large variation in the level of histamine in different types of fish is due to the differential activation of histamine-producing bacteria depending on the environmental conditions where the fish is caught, such as the temperature, the salt content and pollution rate of the region where the fish is caught; feeding behaviour; geographic location of the fish, storage and transportation conditions of the fish after it is caught and the conditions prevailing at the retail sites namely the water available to clean the fish and the time offered to sell the fish [18-20].

\section{pH determination}

For both fish species, there was a negligible increase in $\mathrm{pH}$ after 8 hours of storage [Table 4]. The $\mathrm{pH}$ increased from 6.72 (T0) to 6.81 (T8) and from 7.01 (T0) to 7.25 (T8) in BET and SE respectively. According to FAO (2015), a pH of fresh fish of $\leq 6.2$ is indicative of good quality. However, $\mathrm{pH}$ values exceeding 6.5 usually imply microbial breakdown of protein as well as the release of amino acids and its conversion to ammonia due to the onset of microbial spoilage.

\section{Microbial load}

Total Viable Count (TVC)

TVC recovered from fish samples varied with fish species, retail sites and sampling time [Table 5]. TVC varied between $10^{6}$ to $10^{7} \mathrm{cfu} / \mathrm{g}$. An increase in the TVC was observed from T0

Table 4: Mean $\mathrm{pH}$ and temperature readings for fish purchased from both retail sites.

\begin{tabular}{|c|c|c|c|c|c|}
\hline & & \multicolumn{2}{|c|}{ Market } & \multicolumn{2}{c|}{ Supermarket } \\
\hline Fish species & Analysis time & T0 & T8 & T0 & T8 \\
\hline BET & $\mathrm{pH}$ & $6.7 \pm 0.03$ & $6.7 \pm 0.04$ & $6.8 \pm 0.03$ & $6.8 \pm 0.04$ \\
\cline { 2 - 6 } & $\begin{array}{c}\text { Temperature } \\
\left({ }^{\circ} \mathrm{C}\right)\end{array}$ & 27.2 & 26.5 & 28.3 & 27.0 \\
\hline $\mathrm{SE}$ & $\mathrm{pH}$ & $7.1 \pm 0.08$ & $7.1 \pm 0.07$ & $7.1 \pm 0.06$ & $7.2 \pm 0.05$ \\
\cline { 2 - 6 } & Temperature $\left({ }^{\circ} \mathrm{C}\right)$ & 27.1 & 26.8 & 27.5 & 26.9 \\
\hline \multicolumn{7}{|c|}{} \\
\hline
\end{tabular}

to T8 however it was not statistically significant $(P>0.05)$. An increase in the TVC during extended display is to be expected, as fresh fish is an extremely perishable product. Indeed, it is highly susceptible to microbial attack, which intensifies during storage as a result of the direct and indirect temperature abuse on the fish, thereby increasing the number of microorganisms [21]. After 8 hours of display, TVC values attained a maximum value of $1.23 \times 10^{7}$ and $8.17 \times 10^{7} \mathrm{cfu} / \mathrm{g}$ for BET and SE respectively. Statistical analysis did not reveal any significant differences $(\mathrm{P}>0.05)$ in the TVC level of the two fish species sampled at T0 or T8. Hakkimane and Rathod [22], reported TVC in fresh Indian Mackerel, a scombroid fish, ranging from $10^{4}$ to $10^{9} \mathrm{cfu} / \mathrm{g}$ and that for fresh Lactarius lactarius, a nonscombroid fish, to be ca. $5.5 \times 10^{4} \mathrm{cfu} / \mathrm{g}$. It is generally believed that the population of TVC ranging from $5 \times 10^{5}$ to $10^{7} \mathrm{cfu} / \mathrm{g}$ is considered acceptable for fresh fish and TVC population exceeding $10^{7} \mathrm{cfu} / \mathrm{g}$ constitutes a ground for rejection of fish [23] due to microbial spoilage, which starts when the TVC exceeds $10^{7} \mathrm{cfu} / \mathrm{g}$ [24]. In this study, TVC did not exceed the maximum acceptable limit by specified as ICMSF [23] even after extended storage at ambient temperature. According to a report issued by Sea Fish (2011), TVC should not be the sole index of freshness of fish. TVC in the range of $1 \times 10^{5}$ to $1 \times 10^{6}$ is normally obtained for fish that are freshly caught. A better approach is to identify specific spoilage organisms (SSO) in the fish such as Shewanella or Pseudomonas species. Hence, this study also investigated the presence and level of other spoilage index organisms including Shewanella and Pseudomonas as described later in the text.

\section{Yeast and Mold Counts (YMC)}

There was an increase, albeit statistically insignificant (P > 0.05), in the level of YMC from T0 to T8 for all SE purchased from market and supermarket as well as BET purchased from the supermarket (Table 5). A general increase was observed in the yeast and mold counts after 8 hours of display although the maximum level reached $\left(10^{4}\right.$ to $\left.10^{7} \mathrm{cfu} / \mathrm{g}\right)$ was relatively lower than the TVC at corresponding times. An increase in YMC over the 8-hour period was observed for both fish species purchased from supermarket although an atypical decrease was seen for BET bought from the market. In general no significant difference was observed for any species $(\mathrm{P}>0.05)$. According to El-Deen and El-Shamery [25], for the analysis of fresh Lethrinus elongates stored at room temperature, YMC varied from $1.0 \times 10^{1}$ to $6.6 \times 10^{1}$; a level that was well below the range observed in the present study. It is to be noted that since yeasts are psychrotrophic and halo-tolerant, they are important fish spoilage agents [26].

\section{Marine organisms}

The level of marine organisms isolated on Zobell Marine Agar fell in the range of $10^{5}-10^{7} \mathrm{cfu} / \mathrm{g}$. A significance increase in the level of marine organisms $(\mathrm{P}<0.05)$ was observed in $\mathrm{SE}$ over the 8-hour period while no difference was seen for BET fish [Table 5]. In addition, a higher population of marine organisms was noted as compared to that of total viable count. According to a research study done by Hakkimane and Rathod [22], fresh Lactarius lactarius contained a higher range of marine organisms isolated on Zobell Marine Agar $\left(2.4 \times 10^{2}\right.$ to $\left.5.3 \times 10^{6} \mathrm{cfu} / \mathrm{g}\right)$ than TVC $\left(2.9 \times 10^{3}\right.$ to $\left.2.7 \times 10^{6} \mathrm{cfu} / \mathrm{g}\right)$. 


\begin{tabular}{|c|c|c|c|c|c|c|c|c|c|}
\hline \multirow[t]{2}{*}{$\begin{array}{c}\text { Fish } \\
\text { species }\end{array}$} & \multirow[t]{2}{*}{$\begin{array}{l}\text { Retail } \\
\text { sites }\end{array}$} & \multicolumn{2}{|c|}{$\begin{array}{c}\text { TVC } \\
(\log \mathrm{cfu} / \mathrm{g})\end{array}$} & \multicolumn{2}{|c|}{$\begin{array}{l}\text { Yeast and molds } \\
\quad(\log \mathrm{cfu} / \mathrm{g})\end{array}$} & \multicolumn{2}{|c|}{$\begin{array}{l}\text { Marine organisms } \\
\quad(\log \mathrm{cfu} / \mathrm{g})\end{array}$} & \multicolumn{2}{|c|}{$\begin{array}{l}\text { Presumptive Pseudomonas } \\
(\log \mathrm{cfu} / \mathrm{g})\end{array}$} \\
\hline & & T0 & $\mathrm{T} 8$ & T0 & T8 & T0 & T8 & T0 & T8 \\
\hline BET & Supermarket & $6.87 \pm 0.6^{\mathrm{a}}$ & $7.11 \pm 0.8^{\mathrm{a}}$ & $3.98 \pm 2.6^{\mathrm{a}}$ & $4.61 \pm 3.14^{\mathrm{a}}$ & $6.45 \pm 0.04^{\mathrm{ab}}$ & $7.74 \pm 0.0^{\mathrm{a}}$ & $4.95 \pm 0.1^{b}$ & $6.59 \pm 0.6^{\mathrm{a}^{*}}$ \\
\hline \multirow[t]{2}{*}{$\mathrm{SE}$} & Market & $6.65 \pm 0.8^{a}$ & $7.38 \pm 0.1^{\mathrm{a}}$ & $5.13 \pm 0.5^{a}$ & $7.11 \pm 0.4^{a}$ & $5.56 \pm 0.3^{c}$ & $7.52 \pm 0.01^{\mathrm{a}}$ & $5.51 \pm 0.1^{\mathrm{b}}$ & $6.38 \pm 0.5^{a^{*}}$ \\
\hline & Supermarket & $6.54 \pm 0.7^{a}$ & $7.29 \pm 0.4^{a}$ & $5.71 \pm 0.7^{a}$ & $4.50 \pm 3.1^{a}$ & $6.49 \pm 0.1^{b}$ & $7.79 \pm 0.0^{a}$ & $5.43 \pm 0.2^{\mathrm{b}}$ & $6.53 \pm 0.3^{\mathrm{a}^{*}}$ \\
\hline *: Mean & ues within th & ame row fo & e same mi & logical pa & $\begin{array}{l}\text { ter followe } \\
(\mathrm{P}>0.05)\end{array}$ & the same & script lett & g. “a”) wer & gnificantly \\
\hline
\end{tabular}

\section{Clostridium perfringens}

C. perfringens was generally not detectable by plating on Iron Sulphite Agar at any retail site except for one fish sample from the supermarket. Many authors have reported that C. perfringens is an autochthonous pathogen that forms part of the normal intestinal flora of fish [27, 28]. On the other hand, other authors have reported $C$. perfringens to be an allochthonous pathogen that is usually introduced in seafood, during its processing, from contaminated water or other sources [23]. The result of this study are somewhat congruent with those of El-Deen and El-Shamery [25], who also reported low counts of Clostridium species in fresh Lethrinus elongates stored at room temperature $(<5 \mathrm{cfu} / \mathrm{g})$.

\section{Pseudomonas species}

Shiny yellow, pink and orange colonies with smooth margin were isolated from most of the samples as presumptive Pseudomonas [Table 5]. However, results of microscopic examination, biochemical tests [Table 6] and PCR identification (data not shown) were contradictory, thus confirming the absence of the microorganism from all samples tested. The absence of Pseudomonas from the microbial flora could be attributed to the fact that the fish analyzed during this study were fished in the summer season and according to some studies, low percent of Pseudomonas species are isolated from the summer season (42\%) as compared to winter (64\%) [29] since pseudomonads are psychrotrophic (cold-loving) or psychrotolerant (cold-tolerant) bacteria.

\section{Vibrio species}

Large, flat and round blue or purple colonies $(1-2 \mathrm{~cm})$ and small, flat and round blue or purple colonies (1-2 mm) characteristic of Vibrio were isolated from SE purchased from the market. Vibrio was isolated on CHROMagar Vibrio medium as specified by Al-Othrubi et al. (2014) [30], but no colonies were obtained on TCBS medium. This could be attributed to the pre-enrichment process for Vibrio, which was done using Buffered Peptone Water instead of Alkaline Peptone Water. Alkaline Peptone Water is considered to be the most suitable enrichment broth containing optimal concentrations of $\mathrm{NaCl}$ for recovery of Vibrio species from the samples [31, 32]. The isolates were identified based on their molecular characteristics. The universal primer, $16 \mathrm{~s}$ rRNA was used to amplify the conserved region of the bacterial DNA.
Table 6: Summary of biochemical test results on suspect Pseudomonas isolates.

\begin{tabular}{||c|c|c|c|c|c|c|}
\hline $\begin{array}{c}\text { Fish } \\
\text { species }\end{array}$ & Location & Isolate & $\begin{array}{c}\text { Oxidase } \\
\text { test }\end{array}$ & $\begin{array}{c}\text { Catalase } \\
\text { test }\end{array}$ & $\begin{array}{c}\text { Methyl } \\
\text { red test }\end{array}$ & $\begin{array}{c}\text { Voges } \\
\text { Proskauer } \\
\text { test }\end{array}$ \\
\hline \multirow{2}{*}{ BET } & Market & P1 & + & + & + & + \\
\cline { 2 - 7 } & Market & P2 & + & + & + & + \\
\cline { 2 - 8 } & Supermarket & P3 & + & + & + & + \\
\hline \multirow{2}{*}{ SE } & Supermarket & P4 & + & + & + & + \\
\cline { 2 - 8 } & Supermarket & P5 & + & + & + & + \\
\cline { 2 - 8 } & Market & P6 & + & + & + & + \\
\hline
\end{tabular}

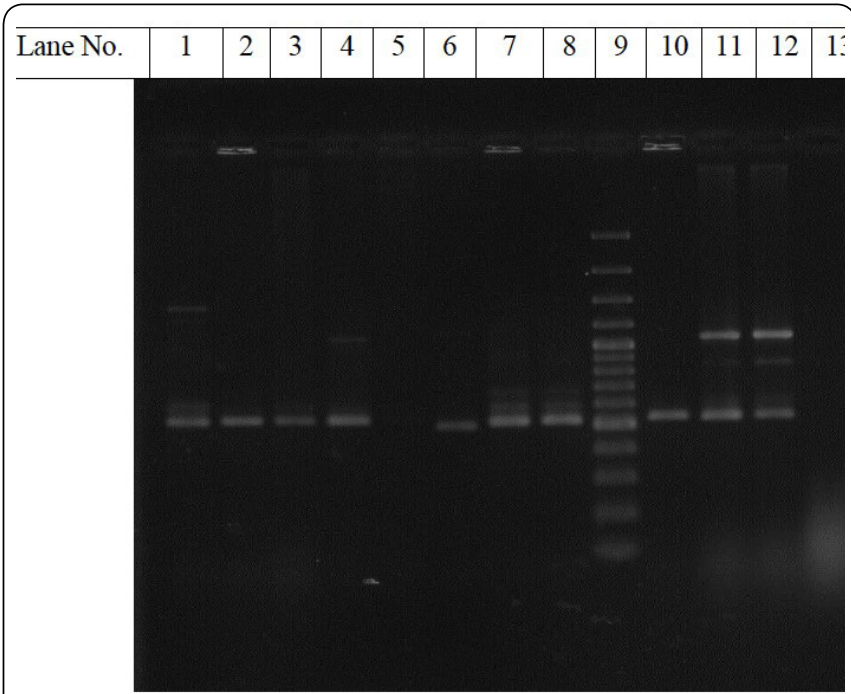

Figure 3: Bands represent PCR products corresponding in size to $16 \mathrm{~s}$ rDNA gene of Vibrio spp. lane 3: Lethrinus nebulosus, market; lane 4: Lethrinus nebulosus, market; lane 5: Lethrinus nebulosus, market, lane 9: DNA ladder; lane 11: Lethrinus nebulosus, market; lane 12: Lethrinus nebulosus, market; lane 13: negative control.

Bands of approximately $500 \mathrm{bp}$ using the O'Gene Ruler ${ }^{\mathrm{TM}}$ 1000 Plus DNA ladder were observed in lane 3 and 5 for suspected Vibrio species [Figure 3]. The PCR products were purified and sent for sequencing. One of the suspected Vibrio colonies (blue colony) isolated only from the SE from the 
market was sent for sequencing and the $16 \mathrm{~S}$ rRNA analysis showed $98 \%$ query coverage for Vibrio parahaemolyticus O1:K33 strain CDC_K4557 (accession no.: CP006008.1) and a 98\% homology for Vibrio species B2-5-2 16S (accession no.: JX134441.1). The other suspected Vibrio colonies (purple colony) isolated only from the SE from the market was sent for sequencing and the 16S rRNA analysis showed 98\% query coverage for Vibrio parahaemolyticus UCM-V493 (accession no.: CP007004.1) and a 98\% homology for Vibrio alginolyticus NBRC15630=ATCC17749 (accession no.: CP006719.1). Indeed, the most predominant Vibrio species isolated from fresh fish is $V$. alginolyticus and $V$. parahaemolyticus $[33,34]$. Since fish analyzed contained low levels of pathogens of vibrios and no pseudomonads, it could be deduced that these fish were caught from relatively unpolluted water as the presence and load of autochthonous (endogenous) pathogens in fish usually reflects the quality of water where the fish has been caught [35]. Polluted water contributes to the proliferation of microorganisms, which could be transmitted to fish [35]; [29]. In a study in India, Pseudomonas species isolated from Megalaspis cordyla and Priacanthus hamrur were high due to disposal of sewage into the seas providing a suitable medium for the multiplication and survival of pathogens [36].

\section{Direct DNA extraction from the fish matrix}

The highly conserved regions of the DNA were targeted using primer Mm453F and Mm631R [37] but no specific band formation was seen after PCR amplification (data not shown) thus confirming the absence of Morganella morganii. Primers SP-1 and SP-2r were designed targeting the highly conserved regions from within the gyrB sequence of Shewanella species [38]. A predicted $422 \mathrm{bp}$ amplicon using these primers would indicate the presence of Shewanella putrefaciens [38] but all the samples gave negative result (data not shown).

\section{Conclusion}

Taken together, the safety, quality and 'freshness' of fresh fish were assessed using a combination of sensorial evaluation techniques as well as microbiological, histamine, physicochemical and molecular analyses immediately upon and eight hours after display under ambient temperature and chilled conditions. Although fish purchased from the market had an initially higher acceptability score than the same fish species purchased from the supermarket, they underwent faster quality deterioration due to the abusive temperature conditions prevailing during display. There was an appreciable increase in the QIM score of fresh fish following the 8-hour display. The TVC load of both fish species sold at both retail outlets was found to increase over the 8-hour display. Furthermore, the presence of $V$. parahaemolyticus and $V$. alginolyticus, which are histamine forming as well as human pathogenic bacteria were also demonstrated. Big Eye Tuna, which is a scombroid fish, was found to harbor higher levels of histamine than Sprangled Emperor fish, a non-scombroid fish. The level of histamine was found to increase after 8 hours of display although it was still within the safe and acceptable limits of $<50 \mathrm{ppm}$. Findings of this study underscore the importance of chilling of fresh fish during display to enhance the safety, quality and consumer appeal of the product.

\section{References}

1. Gram L, Huss HH. 1996. Microbiological spoilage of fish and fish products. Int J Food Microbiol 33(1): 121-137. doi: 10.1016/01681605(96)01134-8

2. Gram L, Dalgaard P. 2002. Fish spoilage bacteria - problems and solutions. Curr Opinion Biotechnol 13(3): 262-266. doi: 10.1016/S09581669(02)00309-9

3. FDA. 2012. Scombrotoxin (histamine) formation. In: Fish and Fishery Products Hazards and Controls Guidance, U.S. Department of Health and Human Services, FDA, USA, pp 114-152.

4. FAO/WHO. 2012. Joint FAO/WHO expert meeting on the public health risks of histamine and other biogenic amines from fish and fishery products. Food and Agriculture Organization/World Health Organization, FAO Headquarters, Rome, Italy, pp 1-111.

5. FAO. 2013. Quality and changes in fresh fish: postmortem changes in fish. Fisheries and Aquaculture Department, Food and Agriculture Organization.

6. Frederiksen M, Osterberg C, Silberg S, Larsen E, Bremner A. 2002. Info-Fisk Development and validation of an internet based traceability system in a Danish domestic fresh fish chain. $J$ Aquat Food Product $T$ 11(2): 13-34. doi: 10.1300/J030v11n02_03

7. Association of Official Analytical Chemists. 1990. AOAC official method 977.13. Official Methods of Analysis, $15^{\text {th }}$ ed. AOAC Inc., Arlington, VA, USA, pp 876-877.

8. Koutsoumanis K, Lambropoulou K, Nychas GJE. 1999. Biogenic and sensory changes associated with the microbial flora of Mediterranean gilt-head seabream (Sparus aurata) stored aerobically at 0,8 and $15^{\circ} \mathrm{C} . \mathrm{J}$ Food Prot 62(4): 392-402.

9. Cheng HR, Jiang N. 2006. Extremely rapid extraction of DNA from bacteria and yeasts. Biotechnol Lett 28(1): 55-59. doi: 10.1007/s10529005-4688-z

10. Bardaki F, Skibinski DO. 1994. Application of the RAPD technique in Tilapia fish species and subspecies identification. Heredity 73(2): 117123. doi:10.1038/hdy.1994.110

11. Martinsdóttir E, Sveinsdottir K, Luten JB, Schelvis-Smit R, Hyldig G. 2001. Reference manual for the fish sector: sensory evaluation of fish freshness. QIM Eurofish, The Netherlands, pp 265-272.

12. Sveinsdottir K, Hyldig G, Martinsdottir E, Jorgensen B, Kristbergsson K. 2002. Application of Quality Index Methods (QIM) Scheme in shelf-life study of farmed Atlantic salmon (Salmo salar). J Food Sci 67(4): 1570-1579. doi: 10.1111/j.1365-2621

13. Auerswald L, Carel M, Andreas LL. 2005. Histamine levels in seventeen species of fresh and processed South African seafood. Food Chem 98(2): 231-239. doi: 10.1016/j.foodchem.2005.05.071

14. Joshi PA, Bhoir VS. 2011. Study of histamine forming bacteria in commercial fish samples of Kalyan city. Int J Curr Sci Res 1(2): 39-42.

15. Frank HA, Yoshinaga DH, Nip WK. 1981. Histamine formation and honeycombing during decomposition of skipjack tuna, Katsuwonus pelamis, at elevated temperatures. Marine Fish Rev 43: 9-14.

16. Mazorra-Manzano MA, Pacheco-Aguilar R, D'ªz-Rojas EI, LugoSa'nchez ME. 2000. Postmortem changes in Black Skipjack muscle during storage in ice. J Food Sci 65(5): 774-779. doi: 10.1111/j.13652621. 2000.tb13585.x

17. FAO. 2015. Proteins from fish and fish products. Food and Agriculture Organization of the United Nations, Fisheries and Aquaculture Department.

18. Fathi AZ, Pooladgar AR, Shamsedin GM, Loni R. 2013. The changes evaluation of biogenic amines (histamine) by HPLC, in shanak yellow fin fish (Acanthopagrus latus) within 18 days of ice storage. Ind J Sci Res and Tech 1(1): 29-34.

19. Smith JS, Kenney PB, Kastner CL, Moore MM. 1995. Biogenic amines 
formation in fresh vacuum-packaged beef during storage at $1^{\circ} \mathrm{C}$ for 120 days. J Food Protect 56(1): 497-532.

20. Yoshinaga DH, Frank HA. 1982. Histamine-producing bacteria in decomposing skipjack tuna (Katsuwonus pelamis). Appl Environ Microbiol 44(2): 447-452.

21. Fang Q, Brockmann S, Botzenhart K, Wiedenmann A. 2000. Improved detection of Salmonella spp. in foods by fluorescent in situ hybridization with 23S rRNA probes: a comparison with conventional culture methods.J Food Prot 66(5): 723-731.

22. Hakkimane S, Rathod JL. 2011. Isolation and enumeration of bacterial flora in false trevally, Lactarius lactarius of Karwar, central west coast of India. Indian J Geomarine Sci 40(4): 583-586.

23. ICMSF. 1986. Microorganisms in Foods: sampling for microbiological analysis. International Commission on Microbiological Specifications for Foods, $2^{\text {nd }}$ ed. Blackwell Scientific Publications, USA.

24. Sichewo-Petronillah R, Gono RK, Muzvondiwa JV, Sizanobuhle N. 2013. Isolation and identification of pathogenic bacteria in edible fish: a case study of fletcher dam in Gweru, Zimbabwe. Int J Sci Res 2(9): 269-273.

25. El-Deen G, E1-Shamery MR. 2010. Studies on contamination and quality of fresh fish meats during storage in Egypt. Acad J Biolog Sci 2(2): 65-74.

26. Betts R. 2010. Microbial update on yeasts \& moulds. Int Food Hyg 24(4): 10-11.

27. CDC. 2014. Clostridium perfringens. Centers for Disease Control and Prevention.

28. Uzal FA, Vidal JE, McClane BA, Gurjar AA. 2010. Clostridium perfringens toxins involved in mammalian veterinary diseases. Open Toxinology J 2: 24-42

29. Yagoub SO. 2009. Isolation of Enterobacteriaceae and Pseudomonas spp. from raw fish sold in fish market in Khartoum state.J Bacteriol Res 1(7): $85-88$
30. Al-Othrubi Saleh MY, Cheah YK, Mirhosseini H, Abdul Hadi Y, Radu S. 2014. Antibiotic resistance of Vibrio parahaemolyticus isolated from cockles and shrimp seafood marketed in Selangor, Malaysia. Clin Microbiol 3(3): 148. doi: 10.4172/2327-5073.1000148

31. Forbes BA, Sahm DF, Weissfeld AS. 1998. Bailey \& Scott's diagnostic microbiology, $10^{\text {th }}$ ed. Mosby, Inc., St. Louis, USA.

32. Sack RB, Tilton RC, Weissfeld AS. 1980. Cumitech 12, Laboratory diagnosis of bacterial diarrhea, American Society for Microbiology, Washington, D.C., USA.

33. Aberoumand A. 2010. Investigation of some microbiological and chemical parameters associated with spoilage of cod fish. World J Fish Marine Sci 2(3): 200-203.

34. Adeleye IA, Daniels FV, Enyinnia VA. 2010. Characterization and pathogenicity of Vibrio Spp. contaminating seafoods in Lagos, Nigeria. J Food Safety 12: 1-9.

35. Emikpe BO, Adebisi T, Adedeji OB. 2011. Bacteria load on the skin and stomach of Clarias gariepinus and Oreochromis niloticus from Ibadan, South West Nigeria: Public health implications.J Microbiol Biotech Res 1(1): 52-59.

36. Sujatha K, Senthilkumar P, Sangeeta S, Gopalakrishnan MD. 2011. Isolation of human pathogenic bacteria in two edible fishes, Priacanthus hamrur and Megalaspis cordyla at Royapuram waters of Chennai, India. Indian J Sci Technol 4(5): 539-541. doi: 10.17485/ijst/2011/v4i5/30057

37. Ferrario C, Ricci G, Borgo F, Fortina MG. 2012. Species-specific DNA probe and development of a quantitative PCR assay for the detection of Morganella morganii. Lett Appl Microbiol 54(4): 292-298. doi: 10.1111/j.1472-765X.2012.03206

38. Venkateswaran K, Duane PM, Dollhopf ME, Douglas PL, Saffarini DA, et al. 1999. Polyphasic taxonomy of the genus Shewanella and description of Shewanella oneidensis sp. nov. Int J Sys Bacteriol 49(2): 705-724. doi: 10.1099/00207713-49-2-705 